\title{
ANALISIS STRATEGI PEMASARAN JAMUR TIRAM PUTIH (PLEUROTUS OSTREATUS) PADA USAHA DAGANG KENANGA DI KECAMATAN AMPENAN KOTA MATARAM
}

\author{
IDA AYU KETUT MARINI1 ${ }^{1)}$, IDA AYU NOPIARI ${ }^{2)}$, IDA BAGUS EKA ARTIKA ${ }^{3)}$
}

\author{
1,2). Fak. Pertanian UNMAS Denpasar PSDKU Mataram \\ 3). Fak. Ekonomi UNMAS Denpasar PSDKU Mataram
}

e-mail : ${ }^{1)}$ yumar4365@gmail.com, ${ }^{2)}$ queen_pino@yahoo.co.id, ${ }^{3)}$ guseka960@gmail.com

\section{ABSTRAK}

Usaha mikro, kecil dan menengah (UMKM) merupakan salah satu entitas ekonomi yang terus digalakkan eksistensinya oleh pemerintah, karena dapat menyerap tenaga kerja, bisa mengurangi pengangguran dan juga meningkatkan pendapatan masyarakat

Penelitian ini dilaksanaan di UD Kenanga, yang memproduksi dan memasarkan jamur tiram yang ada di Kota Mataram. Penelitian ini merupakan penelitian deskriptif yang bertujuan untuk menentukan strategi pemasaran. Penelitian ini dianalisis dengan analisis SWOT.

Hasil penelitian menunjukkan bahwa UD Kenanga secara strategi berada pada kuadran II yang menunjukkan bahwa UD Kenangan berapa pada posisi strategi diversifikasi. Kesimpulan dari penelitian ini adalah Faktor internal dan eksternal yang mempengaruhi strategi pemasaran jamur tiram putih pada UD. Kenanga terdiri dari besaran modal yang terjangkau, tenaga kerja yang berkompeten, kualitas produk yang memadai, lokasi perusahaan strategis, harga bersaing dan mampu memproduksi bibit sendiri. Faktor - faktor yang menjadi kelemahan adalah tingkat produksi rendah, belum melakukan diversifikasi produk jamur tiram putih, tidak adanya sistem pemasaran produk jamur tiram putih, lahan propoduksi terbatas, manajemen keuangan belum profesional, tidak ada kegiatan promosi produk jamur. Faktor - faktor yang menjadi peluang adalah luasnya pangsa pasar, daya beli masyarakat tinggi, adanya intervensi pemerintah,permintaan produk jamur tiram semakin meningkat, kemajuan teknologi. Faktor - faktor yang menjadi ancaman adalah adanya persaiangan antar perusahaan yang sejenis, adanya pergantian musim, tuntutan konsumen terhadap kualitas produk jamur,kenaikan harga bahan bakar.

Saran bagi perusahaan, agar melakukan diversifikasi produk perusahaan Dengan melakukan diversifikasi produk, sehingga dapat meningkatkan pelanggan atau konsumen baru. Bagi pemerintah, agar lebih memperhatikan kebutuhan dari pelaku usaha mikro, terutama peningkatan kegiatan atau pelatihanpelatihan secara teknis terkait dengan produk jamur tiram putih.

Kata kunci : Strategi pemasaran, jamur tiram, analisis SWOT.

\section{ABSTRACT}

Micro, small, and medium enterprises (MSMEs) are one economic entity that continues to be encouraged by the government, because it can absorb labor, can reduce unemployment and also increase people's income

This research is carried out at UD Kenanga, which produces and markets oyster mushrooms in the city of Mataram. This research is a descriptive study that aims to determine marketing strategies. This research is analyzed by SWOT analysis.

The results show that UD Kenanga is strategically in quadrant II which shows that UD Kenanga is in a diversified strategy position. The conclusion of this study is the internal and external factors that influence the marketing strategy of white oyster mushrooms on UD. Kenanga consists of an affordable amount of capital, competent workforce, adequate product quality, strategic company location, competitive prices and able to produce their own seeds. Factors that become weaknesses are low production levels, not yet diversifying white oyster mushroom products, lack of a marketing system for white oyster mushroom products, limited production land, unprofessional financial management, no mushroom product promotion activities. Factors that become opportunities are broad market share, high purchasing power, government intervention, demand for oyster mushroom products is increasing, technological advances. Threatening 
factors are inter-company competition, changing seasons, consumer demands for quality mushroom products, rising fuel prices.

Suggestions for companies, to diversify the company's products By diversifying products, so as to increase new customers or consumers. For the government, to pay more attention to the needs of micro businesses, especially to increase activities or technical training related to white oyster mushroom products.

Keywords: Marketing strategy, Oyster mushroom, SWOT analysis.

\section{PENDAHULUAN}

\section{Latar Belakang}

Salah satu indikator keberhasilan pembangunan ekonomi nasional adalah terbukanya kesempatan kerja bagi masyarakat sehingga dapat meningkatkan pendapatan masyarakat. Namun, kesempatan ini masih sulit karena pertambahan jumlah penduduk dari tahun ke tahun terus meningkat dan diikuti oleh pencari kerja yang yang terus meningkat juga. Suryana (2006) menyatakan bahwa salah satu sasaran pembangunan yaitu meningkatkan persediaan dan memperluas pembagian atau pemerataan bahan pokok yang dibutuhkan untuk bisa hidup, meningkatkan taraf hidup, termasuk menambah atau mempertinggi pendapatan dan penyediaan lapangan kerja dan memperluas jangkauan pilihan ekonomi dan sosial bagi semua individu dan nasional.

Salah satu usaha pemerintah untuk mencapai sasaran tersebut adalah membentuk lembaga- lembaga yang bergerak dalam bidang ekonomi seperti Usaha Mikro Kecil dan Menengah (UMKM). UMKM merupakan lembaga yang banyak menyerap tenaga kerja serta dapat mengurangi jumlah pengangguran, karena usaha kecil ini pada umumnya banyak menyerap tenaga kerja atau bersifat padat karya serta dapat meningkatkan pendapatan masyarakat. Pengembangan usaha mikro kecil dan menengah banyak dilakukan oleh masyarakat di Indonesia mengingat struktur usaha yang berkembang selama ini bertumpu pada keberadaan industri kecil maupun menengah meskipun dengan kondisi yang masih memprihatinkan, baik dari segi nilai tambah maupun dari segi keuntungan yang diperoleh. Usaha mikro, kecil dan menengah di Nusa Tenggara Barat memiliki prospek yang baik untuk dikembangkan sebagai usaha untuk mengatasi pengangguran dan peningkatan pendapatan masyarakat Nusa Tenggara Barat dan sebagai salah satu satu daerah tujuan wisata di Indonesia setelah Pulau Dewata. Salah satu jenis usaha mikro,kecil dan menengah yang mendukung tujuan tersebut adalah usaha industri jamur tiram.

Keberadaan jamur tiram sebagai salah satu jenis bahan pangan sudah cukup lama dikenal dikalangan masyarakat, baik kalangan ekonomi menengah atas maupun bawah. Jamur juga dapat dikategorikan sebagai salah satu komoditas pertanian organik, karena proses budidaya tanaman jamur tidak menggunakan pupuk sintesis ataupun bahan kimia lainnya. Keunggulan inilah menjadikan jamur sebagai salah satu komoditas pertanian pilihan yang semakin populer di masyarakat.

Berdasarkan pengamatan yang telah dilakukan sebelumnya, sebagian besar produsen jamur tiram di kota Mataram terdapat di daerah Ampenan. Salah satu industri rumah tangga yang memproduksi jamur tiram adalah UD Kenanga. Industri rumahtangga ini masih mengandalkan pemasaran produksinya secara tradisional.

Ada beberapa permasalahan yang dihadapi oleh UD. Kenanga yakni : volume produk yang belum bisa memenuhi permintaan pasar, dan semakin menjamurnya usaha budidaya jamur tiram, sebagai pesaing dari UD Kenanga. Oleh karena itu, perusahaan memerlukan langkah yang strategis untuk mengembangkan usahanya, dalam menghadapi permasalahan guna meraih peluang, agar kontinuitas serta tujuan perusahaan bisa tercapai. Identifikasi masalah dalam penelitian ini bahwa keberhasilan dalam pemasaran usaha jamur tiram agar tujuannya dapat tercapai dipengaruhi oleh beberapa faktor yaitu faktor eksternal dan faktor internal

\section{Rumusan Masalah}

Dari diuraikan di atas dapat dirumuskan suatu rumusan masalah yaitu

1. Faktor-faktor apa saja yang menjadi kekuatan, kelemahan,peluang dan tantangan pada perusahaan Jamur Tiram Putih(Pleurotus Ostreotus) Usaha Dagang Kenanga di Kecamatam Ampenan Kota Mataram

2. Strategi pemasaran apa yang tepat diterapkan perusahaan Jamur Tiram Putih(Pleurotus Ostreotus) pada Usaha Dagang Kenanga di Kecamatan Ampenan Kota Mataram. 


\section{Tujuan Penelitian}

1. Untuk mengetahui faktor-faktor kekuatan, kelemahan, peluang dan tantangan pada perusahaan Jamur Tiram Putih(Pleurotus Ostreotus) UD Kenanga

2. Untuk menentukan strategi pemasaran yang tepat diterapkan oleh perusahaan jamur tiram putih (Pleurotus Ostreotus) pada Usaha Dagang (UD) Kenanga di Kecamatan Ampenan Kota Mataram.

\section{LANDASAN TEORI}

Kotler (2000), menyatakan bahwa pemasaran adalah proses sosial dan manajerial ketika individu dan kelompok mendapatka apa yang mereka butuhkan dan inginkan dengan menciptakan, menawarkan dan menukarkan produk yang bernilai dengan pihak lain. Sementara menurut Rangkuti (2002), strategi pemasaran merupakan sekumpulan tindakan pemasaran yang terintegrasi dalam rangka memberikan nilai kepada konsumen dan menciptakan keunggulan bersaing bagi perusahaan. Strategi pemasaran harus bersifat distinctived (tidak mudah ditiru oleh pesaing dan spesifik) dan didukung oleh semua potensi yang dimiliki perusahaan secara optimal.

Pertanian organik adalah teknik budidaya pertanian yang menghandalkan bahan bahan alami tanpa menggunakan bahan-bahan kimia sintetis. Tujuan utama pertanian organik adalah menyediakan produkproduk pertanian, terutama bahan pangan yang aman bagi kesehatan produsen dan konsumennya serta tidak merusak lingkungan. Gaya hidup sehat demikian telah melembaga secara internansional yang mensyaratkan bahwa produk pertamian harus beratribut aman dikonsumsi ( food safety attributes), kandunngan nutrisi tinggi (nutrytional attributes), dan ramah lingkungan(eco-labelling attributes). Preferensi konsumen seperti ini menyebabkan permintaan produk pertanian organik dunia meningkat pesat (Prasetya, 2010 dalam Dina,dkk, 2010).

\section{METODE PENELITIAN}

\section{Jenis Penelitian}

Penelitian ini bersifat deskriptif yaitu penelitian yang dilakukan untuk melakukan pemecahan masalah pada saat sekarang, melalui pengumpulan dan pengolahan data kemudian melakukan penarikan kesimpulan. Penelitian dilakukan dengan cara melakukan analisis lingkungan eksternal dan internal untuk mendapatkan strategi pemasaran yang digunakan oleh UD. Kenanga dalam mengembangkan usaha jamur tiram putih (Pleurotus Ostreotus)

\section{Jenis Dan Sumber Data}

Data yang digunakan pada penelitian adalah jenis data kualitatif yaitu data yang berupa keterangan atau bukan angka, pada penelitian ini adalah data faktor ekternal dan internal dari UD. Kenanga di Kecamatan Ampenan Kota Mataram. Sumber data pada penelitian ini adalah data primer dan sekunder. Data primer adalah data yang diperoleh secara langsung dari responden dan data sekunder adalah data yang diperoleh dari dinas terkait.

\section{Teknik Pengumpulan Data}

Data dikumpulkan melalui wawancara langsung pada responden yang pada penelitian ini adalah pemilik perusahaan, dan teknik dekumentasi yaitu suatu metode pengumpulan data dari berita koran, internet atau dokumen-dokumen tertulis/gambar.

\section{Analisis Data}

Analisa data yg digunakan pada penelitian ini adalah analisa faktor-faktor lingkungan, baik lingkungan internal maupun lingkungan eksternal yang dikenal dengan analisa SWOT. Menurut Fred David $(1997 ; 134)$, analisa SWOT adalah metode perencanaan strategis yang berfungsi untuk mengevaluasi kekuatan, kelemahan, peluang dan ancaman suatu perusahaan. Proses ini melibatkan penentuan tujuan yang spesifik dari spekulasi bisnis dan mengidentifikasikan faktor internal dan eksternal yang mendukung atau yang tidak dalam mencapai tujuan tersebut. Adapun langkah- langkah dalam pembuatan matriks SWOT :

1). Identifikasi faktor internal dan eksternal,2).Penentuan peringkat(rating), bobot dan skor pada tiap faktor,3). Penentuan matriks posisi, 4).Perumusan faktor-faktor strategis dengan matriks SWOT 


\title{
HASIL DAN PEMBAHASAN
}

\section{Kekuatan Usaha Dagang Jmur Tiram Kenanga}

\author{
a.Besarnya Modal Terjangkau
}

Berdasarkan hasil wawancara dengan pemilik perusahaan jamur tiram kenanga bahwa modal awal dari usaha jamur tiram sebesar Rp.2.000.000. Hal ini merupakan kekuatan dari usaha jamur tiram bahwasannya untuk mengembangkan suatu bisnis jamur tiram tidak harus menyediakan modal yang besar. Dengan modal yang dapat dijangkau oleh semua lapisan masyarakat, usaha ini bisa dijalankan.

\section{b.Ketersediaan Tenaga Kerja Yang Kompeten}

Berdasarkan data yang ada , tenaga kerja pada Usaha Dagang Jamur Kenangan memiliki tenaga kerja sebanyak 6 (enam) orang yang terdiri 1(satu ) orang manajer, 1(satu) orang bendahara, 1(satu) orang sekretaris, dan 3 (tiga) orang bagian pemasaran. Manajer UD. Kenanga sekaligus sebagai pemilik, yang sudah berpengalaman dalam melaksanakan budidaya jamur, sehingga sudah dipercaya sebagai orang tua asuh dalam membina usaha-usaha yang sejenis.

\section{c.Kualitas Produksi Memenuhi Kreteria}

Produk jamur tiram dikemas dengan plastik yg berkualitas,kedap udara sehingga produk bisa bertahan kesegaran dalam beberapa hari kedepan.

\section{d.Lokasi Yang Srategis}

Usaha Dagang Jamur Kenanga terletak di Kota Mataram tepatnya di dusun Karang Buyuk, Kecamatan Ampenan. Lokasi UD.Kenanga mudah dijangkau karena lokasinya mudah dilalui oleh semua jenis kendaraan.

\section{e.Harga Bersaing}

Berdasarkan hasil wawancara dengan pemilik perusahaan, rata-rata harga jual jamur tiram berkisar antara Rp.20.000 - 25.000 per kilogram. Perusahaan memperoleh keuntungan rata-rata perbulan sekitar Rp.2.000.000 atau sebesar Rp.8.000.000 per proses produksi atau selama 4 bulan.

\section{f.Mampu Memproduksi Bibit Jamur Sendiri}

UD kenanga dalam perjalana usahanya dimana awal dari perusahaan dimulai dari membeli bibit jamur dari perusahaan yg sejenis, lambat laun seiring dengan bertambahnya permintaan atau pelanggan maka Usaha Dagang Kenanga berusaha membuat bibit sendiri, secara tidak langsung perusahaan dapat mengurangi biaya operasioanalnya.

\section{Kelemahan Usaha Dagang Kenanga Jamur Tiram}

\section{a.Tingkat Produksi Rendah}

Produksi jamur tiram yang diproduksi baru bisa mencapai 0,02 sampai 0,07 gram per baglog sampai $\mathrm{kg}$ atau rata - rata 0,045 gram per sekali panen, secara normal produksi jamur per baglog bisa mencapai 0,49 gram per baglog (Meutia, 2018) atau dengan kata lain bahwa produktivitas usaha masih dalam kategori rendah

\section{b.Belum melakukan diversifikasi produk}

Produk Jamur yang diproduksi UD. Kenanga adalah jamur tiram putih dalam bentuk produk fresh, yang dibungkus dengan kantong plastik polipropilen dengan tebal 0,03 $\mathrm{mm}$.

\section{c.Belum adanya Sistem Pemasaran Yang Memadai}

Sistem penjualan produk jamur tiram kenanga lebih banyak di jual di pasar tradisional, sebagian kecil dijual melalui distributor. Belum ada upaya pemasaran produk melalui iklan, selama ini informasi tentang produk jamur tiram kenanga dikenal oleh masyarakat hanya melalui mulut ke mulut.

\section{d.Lahan Produksi Terbatas}

Berdasarkan hasil survei luas lahan yang tersedia untuk produksi hanya bisa menampung baglog sebanyak 500 baglog. , menurut pemilik perusahaan bahwa lokasi produksi akan di perluas sehingga bisa menampung baglog minimal 2 kali jumlah semula.

\section{e.Manajemen Keuangan Belum Profesional}

Manajeman keuangan pada perusahaan ini dipegang oleh karyawan yang notabennya tidak memiliki keahlian di bidang manajemen keuangan, sehingga alur keuangan dibuat secara manual dan sederhana. 


\section{f.Kurangnya Promosi}

Promosi merupakan salah satu kegiatan atau upaya untuk mengimformasikan atau menawarkan produk atau jasa dengan tujuan menarik calon konsumen untuk membeli atau mengkonsumsi produk. Adapun tujuan dari promosi adalah untuk mendapatkan kenaikan angka penjualan dan meningkatkan profit atau keuntungan. Ada tiga cara untuk menawarka prooduk kepada konsumen, bisa secara fiisik,media tradisional dan media digital. Diantara ketiga cara tersebut yang paling efisien adalah dengan cara media digital karena penyebarannya lebih luas dan relatif cepat. Berdasarkan hasil survei pada lokasi penelitian, UD Kenanga hanya mempromosikan produknya bila ada event-event tertentu di daerah lokasi seperti perayaan Ulang Tahun Kota Mataram.

\section{Peluang Usaha dalam Pemasaran Jamur Tiram Putih (Pleurotus Ostreotus)}

\section{a.Luasnya Pangsa Pasar Jamur Tiram}

Ada beberapa jenis jamur konsumsi, diantaranya adalah jamur tiram putih yang mana jamur tiram putih ini merupakan salah satu jamur yang paling digemari oleh masyarakat, secara proporsional bisa mencapai $30 \%$ dari semua jamur konsumsi yang ada di Indonesia. Segmentasi pasar jamur tiram putih adalah dari pasar tradisional, mimi market, super market, rumah makan, restoran.

\section{b.Daya Beli Masyarakat Relatif Tinggi}

Daerah Nusa Tenggara Barat merupakan salah satu daerah destinasi wisata setelah Bali, ini merupakan salah satu faktor yang dapat menggerakan perekonomian daerah Nusa Tenggara Barat, pergerakan yang dinamis memberikan suatu indikasi bahwa daya beli masyarakat akan semakin meningkat.

\section{c.Intervensi Pemerintah}

Pemerintah Nusa Tenggara Barat melakukan kerjasama dengan pelaku UMKM dalam memerangi kemiskinan, lewat pelatihan- pelatihan yang kerap dilaksanakan dengan tujuan untuk meningkatkan ketrampilan dan meningkatkan manajemen usaha. Diharapkan kedepannya para pelaku bisnis bisa menciptakan lapangan kerja seluas-luasnya bagi masyarakat Nusa Tenggara Barat. UD Kenanga pada tahun 2015 berkesempatan dalam mengikuti pelatihan manajemen keuangan yang dilaksanakan oleh Depertemen Perindustrian dan Perdagangan Provinsi Nusa Tenggara Barat.

\section{d. Selera Masyarakat Terhadap Produk Jamur Tiram Cukup Tinggi}

Jamur tiram putih merupakan salah satu jenis jamur yang sudah sangat dikenal dikalangan semua lapisan masyarakat, karena kandungan gizinya yang tinggi, rasanya enak dan dapat diolah menjadi berbagai produk olahan.

\section{e.Tekonologi}

Kemajuan teknologi yang begitu pesat di era globalisasi ini memungkinkan bagi pengusaha jamur tiram untuk mengembangkan usahanya lebih cepat dan lebih efisien.

\section{Ancaman Usaha dalam Pemasaran Jamur Tiram Putih (Pleurotus Ostreotus)}

\section{a. Adanya Persaingan Antara Pembudidaya Jamur Tiram}

Adanya peluang yang cukup besar dalam menjalankan bisnis jamur tiram, tidak menutup kemungkinan banyak orang tertarik melakukan bisnis ini, sehingga akan terjadinya peningkatan jumlah pembudidaya jamur tiram putih. Terjadinya peningkatan jumlah pelaku bisnis jamur tiram maka akan menyebabkan peningkatan persaingan, dan ini merupakan ancaman bagi pelaku bisnis jamur tiram UD. Kenanga.

\section{b.Pengaruh Pergantian Musim/ cuaca Terhadap Usaha Jamur Tiram}

Musim kemarau merupakan salah satu faktor ekternal yang sangat mempengaruhi pertumbuhan jamur tiram, karena suhu udara yang tinggi akan bisa menghambata pertumbuhan jamur dan akan berimplikasi langsung terhadap tingkat produksi. Pertumbuhan jamur tiram memerlukan suhu dingin dengan tingkat kelembaban udara yang tinggi.

\section{c.Tuntutan Konsumen Terhadap Kualitas}

Kualitas jamur dapat dilihat dari penampilan fisiknya, bentuk tudung jamur bul;at tidak pecah warna putih bersih tidak kekuningan, dan tanpa menyertakan batang. 


\section{d.Kenaikan Harga Bahan Bakar}

Sterilisasi baglog dilakukan agar bakteri-bakteri atau jamur- jamur liar yang ada dalam media tidak tumbuh saat baglog diisi dengnan bibit jamur tiram putih. Sterilisasi dilakukan dengan merebus atau men stem baglog dengan menggunakan tungku yang bisa dibuat dari drum. Proses sterilisasi dilakukan pada suhu $100^{\circ} \mathrm{C}$ dalam waktu $8-10$ jam, dengan menggunakan kayu bakar sebagai bahan bakar. Ketersediaan bahan bakar kayu di kota mataram merupakan kendala utama dalam proses sterilisasi.

\section{Strategi Pemasaran Usaha Jamur Tiram Putih(Pleurotus Ostreotus)}

Setelah diketahui faktor-faktor internal dan eksternal pada pemasaran jamur tiram putih didaerah penelitian, tahap selanjutnya adalah pembuatan tabel matrix internal dan ekternal ( IFAS dan EFAS Matrix) seperti pada Tabel 1 berikut ini :

Tabel 1. Matrix Evaluasi Faktor Strategi Internal (IFAS)

\begin{tabular}{|c|c|c|c|c|}
\hline Faktor- & tor Strategi Internal & Rating & Bobot & Skor \\
\hline Kekuat & (Strength) & & & \\
\hline 1. & Besaran modal terjangkau & 3 & 0.05 & 0.15 \\
\hline 2. & Tenaga kerja yg kompeten & 4 & 0.15 & 0.60 \\
\hline 3 & Kualitas produk sudah memadai & 3 & 0.10 & 0.30 \\
\hline 4 & Lokasi perusahaan strategis & 4 & 0.10 & $\overline{0.40}$ \\
\hline 5 & Harga bersaing & 3 & 0.05 & 0.15 \\
\hline 6 & Mampu berproduksi bibit sendiri & 3 & 0.05 & 0.15 \\
\hline Total $(1$ & & 14 & 0.50 & 1.75 \\
\hline Kelema & (Weakness) & & & \\
\hline 1 & Tingkat Produksi Rendah & 3 & 0.15 & 0.45 \\
\hline 2 & Belum Adanya Diversifikasi Produk & 4 & 0.10 & 0.40 \\
\hline 3 & Belum Adanya Sistem Pemasaran & 3 & 0.10 & 0.30 \\
\hline 4 & Lahan Produksi Terbatas & 4 & 0.05 & 0.20 \\
\hline 5 & Manaj. Keuanan Belum Profisional & 4 & 0.05 & 0.20 \\
\hline 6 & Kurangnya promosi & 3 & 0.05 & 0.15 \\
\hline Total $(2$ & & 10 & 0.50 & 1.70 \\
\hline Total $(1$ & & & 1.00 & 0.05 \\
\hline
\end{tabular}

Sumber : Data Primer Diolah (2019)

Tabel 1. menunjukkan bahwa faktor internal yang dimiliki oleh UD Kenanga berupa kekuatan memberikan efek positip terbesar yaitu sebesar 0,6 terhadap pangsa pasar adalah faktor tenaga kerja yang kompeten. Sedangkan dari faktor kelemahan, ada dua faktor memberi pengangaruh negatip yaitu sebesar 0,45 adalah faktor tingkat produksi rendah dan faktor belum adanya diversifikasi produk merupakan faktor terbesar kedua yang memberikan pengaruh negatip. Sedangkan skor untuk faktor eksternalnya selengkapnya ada pada Tabel 2 berikut ini:

Tabel 2.Matrix Evaluasi Faktor Strategi Eksternal (EFAS)

\begin{tabular}{|c|l|c|c|c|}
\hline \multicolumn{2}{|l|}{ Faktor-faktor Strategi Eksternal } & Rating & Bobot & Skor \\
\hline Opportunity(Peluang) & & & \\
\hline 1 & Luasnya Pangsa Pasar & 4 & 0.13 & 0.52 \\
\hline 2 & Daya Beli Masyarakat & 4 & 0.13 & 0.52 \\
\hline 3 & Intervensi Pemerintah & 2 & 0.05 & 0.10 \\
\hline 4 & Permintaan semakin meningkat & 3 & 0.10 & 0.30 \\
\hline 5 & Teknologi & 2 & 0.09 & 0.18 \\
\hline Total (1) & 15 & 0.50 & 1.62 \\
\hline Ancaman (Threat) & & & \\
\hline 1 & Adanya Persaingan & 4 & 0.20 & 0.80 \\
\hline 2 & Adanya Pergantian Musim & 2 & 0.05 & 0.10 \\
\hline 3 & Tuntutan konsumen terhadap kualitas & 2 & 0.10 & 0.20 \\
\hline 4 & Kenaikan Harga Bahan bakar & 3 & 0.15 & 0.45 \\
\hline Total (2) & 6 & 21 & 1.00 & -1.38 \\
\hline Total (1 -2)
\end{tabular}

Sumber : Data Primer, Diolah (2019) 
Tabel 2. menunjukkan bahwa dua faktor yang memberikan nilai positip tertinggi yaitu faktor luas pangsa pasar dan daya beli masyarakat sebesar 0,52 bila dibandingkan dengan faktor ekternal lainnya. Hal ini menunjukkan perusahaan UD. Kenanga memiliki peluang yang cukup besar dalam mengembangkan usahanya. Dengan adanya peluang yang besar, persaingan pasar juga besar yaitu sebesar 0,80. Jika kedua faktor-faktor eksternal yaitu peluang dan ancaman dijumlahkan maka skor untuk faktor ekternal memiliki skor sebesar -1,38 hal ini mengindikasikan bahwa perusahaan jamur tiram putih (Pleurotus Ostreotus) pada UD. Kenanga memiliki ancaman dalam mengembangkan usahanya.

Tabel 3. Penggabungan Matrix Evaluasi Faktor Internal dan Internal Pemasaran

\begin{tabular}{|c|c|c|c|c|}
\hline \multicolumn{2}{|c|}{ Faktor-faktor Strategi Internal } & Rating & Bobot & Skor \\
\hline \multicolumn{5}{|c|}{ Kekuatan (Strength) } \\
\hline 1. & Besaran modal terjangkau & 3 & 0.05 & 0.15 \\
\hline 2. & Tenaga kerja yg kompeten & 4 & 0.15 & 0.60 \\
\hline 3 & Kualitas produk sudah memadai & 3 & 0.10 & 0.30 \\
\hline 4 & Lokasi perusahaan strategis & 4 & 0.10 & 0.40 \\
\hline 5 & Harga bersaing & 3 & 0.05 & 0.15 \\
\hline 6 & Mampu berproduksi bibit sendiri & 3 & 0.05 & 0.15 \\
\hline \multicolumn{2}{|c|}{ Total (1) } & 14 & 0.50 & 1.75 \\
\hline \multicolumn{5}{|c|}{ Kelemahan (Weakness) } \\
\hline 1 & Tingkat Produksi Rendah & 3 & 0.15 & 0.45 \\
\hline 2 & Belum Adanya Diversifikasi Produk & 4 & 0.10 & 0.40 \\
\hline 3 & Belum Adanya Sistem Pemasaran & 3 & 0.10 & 0.30 \\
\hline 4 & Lahan Produksi Terbatas & 4 & 0.05 & 0.20 \\
\hline 5 & Manaj. Keuanan Belum Profisional & 4 & 0.05 & 0.20 \\
\hline 6 & Kurangnya promosi & 3 & 0.05 & 0.15 \\
\hline \multicolumn{2}{|c|}{ Total (2) } & 10 & 0.50 & 1.70 \\
\hline \multicolumn{2}{|c|}{ Total $(1-2)$} & & 1.00 & 0.05 \\
\hline \multicolumn{2}{|c|}{ Faktor-faktor Strategi Eksternal } & Rating & Bobot & Skor \\
\hline \multicolumn{5}{|c|}{ Opportunity(Peluang) } \\
\hline 1 & Luasnya Pangsa Pasar & 4 & 0.13 & 0.52 \\
\hline 2 & Daya Beli Masyarakat Tinggi & 4 & 0.13 & 0.52 \\
\hline 3 & Intervensi Pemerintah & 2 & 0.05 & 0.10 \\
\hline 5 & Permintaan semakin meningkat & 3 & 0.10 & 0.30 \\
\hline 5 & Teknologi & 2 & 0.09 & 0.18 \\
\hline \multicolumn{2}{|c|}{ Total(1) } & 15 & 0.50 & 1.62 \\
\hline \multicolumn{5}{|c|}{ Ancaman (Threat) } \\
\hline 1 & Adanya Persaingan & 4 & 0.20 & 0.80 \\
\hline 2 & Adanya Pergantian Musim & 2 & 0.05 & 0.10 \\
\hline 3 & Tuntutan konsumen terhadap kualitas & 2 & 0.10 & 0.20 \\
\hline 4 & Kenaikan Harga Bahan bakar & 3 & 0.15 & 0.45 \\
\hline \multicolumn{2}{|c|}{ Total (2) } & 6 & $\underline{0.50}$ & 3.00 \\
\hline \multicolumn{2}{|c|}{ Total $(1-2)$} & 21 & 1.00 & -1.38 \\
\hline
\end{tabular}

Sumber : Data Primer Diolah, 2019

Berdasarkan Tabel 3. diatas dapat dijelaskan bahwa selisih faktor strategis internal (kekuatan kelemahan) adalah sebesar 0,05 yang artinya pengaruh kekuatan lebih besar dibandingkan dengan kelemahan terhadap pengaruh pemasaran jamur tiram putih di UD. Kenanga. Sedangkan selisih faktor strategis ekternal (peluang - ancaman) adalah sebesar -0,38 yang artinya pengaruh ancaman lebih besar dibandingkan peluang terhadap pengaruh pemasaran jamur tiram di UD. Kenanga. Berdasarkan penggabungan matrix evaluasi faktor internal dan eksternal tersebut maka dapat diketahui posisi strategis pemasaran jamur tiram putih UD. Kenanga Kota Mataram. Posisi tititk koordinatnya dapat dilihat seperti pada gambar dibawah ini : 


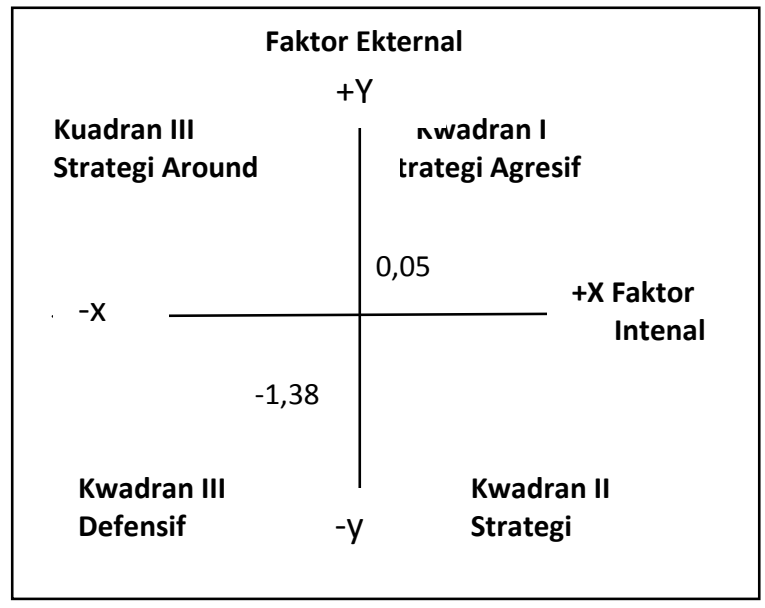

Berdasarkan Gambar 1. posisi strategi pemasaran jamur tiram putih UD. Kenanga Kota Mataram berada pada kuadran II yaitu posisi strategi Deversifikasi (Positip, negatif). Posisi ini menandakan suatu perusahaan cukup kuat namun menghadapi banyak tantangan.

Menurut David,(2002) bahwa banyak alternatif strategi yang dapat digunakan untuk mengembangkan usaha dalam berbagai bentuk. Alternatif tersebut diantaranya : strategi integrasi, strategi intensif, strategi diversifikasi dan strategi defensif.

Lebih lanjut dijelaskan strategi diversifikasi dapat dilakukan dengan menerapkan strategi diversifikasi konsentrik, strategi diversifikasi konglomerat, strategi diversifikasi horisontal. Strategi diversifikasi konsentrik dapat dilakukan dengan cara menambah produk atau jasa baru yang masih berkaitan dengan produk atau jasa lama. Diversifikasi Konglomerat dapat dilakukan dengan menambahkan produk atau jasa baru yang tidak berkaitan dengan produk atau jasa lama, sedangkan strategi Diversifikasi horisontal dengan cara menambahkan produk atau jasa baru yang tidak berkaitan dengan pelanggan saat ini.

Setelah mengetahui hasil pada gambar diatas, maka perlu dilakukan analisis dengan menyusun faktorfaktor strategis dalam matriks SWOT :

\begin{tabular}{|c|c|}
\hline NTERNAL & $\begin{array}{l}\text { KEKUATAN } \\
\text { 1. Besaran modal terjangkau } \\
\text { 2. Tenaga kerja yang kompeten } \\
\text { 3. Kualitas produk sudah memadai } \\
\text { 4. Lokasi perusahaan strategis } \\
\text { 5. Harga Jamur Bersaing } \\
\text { 6. } \\
\text { Mampu memproduksi bibit sendiri }\end{array}$ \\
\hline $\begin{array}{l}\text { ANCAMAN } \\
\text { 1. Adanya persaingan } \\
\text { 2. Adanya pergantian musim } \\
\text { 3. Tuntutan konsumen terhadap } \\
\text { kualitas } \\
\text { 4. Kenaikan Harga Bahan Bakar }\end{array}$ & $\begin{array}{l}\text { Strategi Diversifikasi } \\
\text { 1. Meningkatkan produksi dengan meningkatkan } \\
\text { produkstivitas kerja dan penambahan sarana } \\
\text { produksi. } \\
\text { 2. Berusaha untuk mempertahankan pelanggan } \\
\text { dengan cara meningkatkan kualitas produk } \\
\text { 3. Berinovasi dengan melakukan diversifikasi produk serta } \\
\text { lebih intensif dalam mempromosikan produk }\end{array}$ \\
\hline
\end{tabular}

Gambar : Matrik SWOT

\section{Keputusan}

Dari hasil analisa matriks SWOT diperoleh kondisi perusahaan jamur tiram putih UD. Kenanga berada pada kondisi yang kuat namun penuh dengan ancaman. Untuk mengatasi atau solusi yang dapat ditempuh oleh UD. Kenanga adalah :

1. Dari segi produk yang dihasilkan oleh UD kenanga, untuk meningkatkan kapasitas produksi per sekali panen dapat dilakukan dengan penambahan jumlah baglog, dimana selama ini jumlah baglog hanya 500 baglog sekali proses produksi. Atau dengan kata lain perlu dilakukan penambahan kapasitas produksi jamur tiram putih. Penambahan jumlah baglog yang akan ditanami benih jamur per orang adalah paling minimum dilakukan dua kali lipat dari sebelumnya yaitu sebanyak 1000 baglog per orang. Selain itu, dapat pula dilakukan dengan penambahan jumlah tenaga kerja, dimana tenaga kerja yang dipekerjakan dalam proses produksi hanya 2 orang. Penambahan tenaga kerja dua kali dari tenaga yang ada akan dapat meningkatkan produksi sebesar $100 \%$ dari produksi yang ada dengan asumsi proses produksi berjalan dengan normal, disamping usaha peningkatan kuantitas produk perlu diadakan perbaikan terhadap kualitas sumberdaya manusianya. Pemerintah Nusa Tenggara Barat sangat intens dalam upaya 
peningkatan kualitas sumberdaya manusia, salah satunya adalah melakukan pembinaan terhadap pelakupelaku bisnis yang masih dalam kategori Usaha Mikro Kecil dan Menengah (UMKM).

2. Untuk mempertahankan pelanggan yang ada, UD Kenanga dapat melakukan suatu terobosan baru atau berinovasi terhadap produk yang ada. Selama ini UD Kenanga memasarkan jenis produk dalam bentuk produk jamur segar saja. Produk jamur segar adalah produk jamur yang dijual setelah dipetik kemudian dikemas dalam kantong plastik propelin agar jamur bertahan dalam waktu yang lebih lama, dengan harga yang bervariasi muai dari Rp1.500 - 5.000. Disamping kualitas fisik jamur, bentuk kemasan juga dapat mempengaruhi minat pelanggan. Produk segar jamur dari UD. Kenanga tidak menyertai label perusahaan, sehingga konsumen yg membeli produk jamur segar dari UD. Kenanga tidak dapat mengenal secara langsung produk dari UD Kenanga.

3. Ketiga, Selain produk segar, UD Kenanga dapat melalukan diversifikasi produk misalnya dengan membuka stand yang menjual makanan siap saji seperti sate jamur, kripik jamur,jamur goreng, sop jamur, bumbu penyedap jamur, tongseng jamurdan lain2. Selain melakukan diversifikasi produk jamur tiram putih, UD. Kenanga juga dapat menambah jenis jamur yang dibudidayakan selain jamur tiram putih((Pleurotus Ostreotu).

4. Disamping usaha mempertahankan pelanggan, usaha untuk memperluas pangsa pasar juga penting dilakukan, pada saat sekarang ini dapat dikalukan secara lebih efisien via internet. Google merupakan media sosial yang dapat dipergunakan sebagai ajang promosi produk jamur dan sekaligus sebagai metode untuk meningkatkan pangsa pasar.

\section{SIMPULAN DAN SARAN}

\section{Simpulan}

Dari hasil penelitian dapat disimpulkan sebagai berikut :

Faktor internal dan eksternal yang mempengaruhi strategi pemasaran jamur tiram putih pada UD. Kenanga :

a. Faktor Kekuatan : besaran modal yang terjangkau, tenaga kerja yang berkompeten, kualitas produk yang memadai, lokasi perusahaan strategis, harga bersaing dan mampu memproduksi bibit sendiri.

b. Faktor kelemahan : tingkat produksi rendah, belum melakukan diversifikasi produk jamur tiram putih, tidak adanya sistem pemasaran produk jamur tiram putih, lahan propoduksi terbatas, manajemen keuangan belum profesional, tidak ada kegiatan promosi produk jamur.

c. Faktor peluang : luasnya pangsa pasar, daya beli masyarakat tinggi, adanya intervensi pemerintah,permintaan produk jamur tiram semak in meningkat, kemajuan teknologi.

d. Faktor ancaman : adanya persaiangan antar perusahaan yang sejenis, adanya pergantian musim, tuntutan konsumen terhadap kualitas produk jamur,kenaikan harga bahan bakar.

\section{Saran-saran}

1. Dari hasil analisa matrix SWOT posisi berada pada kondisi dimana perusahaan jamur tiram putih UD. Kenanga di Kota Mataram memiliki kekuatan, namun dihadapkan pada tantangan. Strategi yang dapat direkomendasikan adalah strategi diversifikasi, yaitu strategi yang menggunakan segala kekuatan yang dimiliki untuk menghadapai segala tantangan yang ada,sehingga tantangan itu bisa berubah menjadi peluang bagi UD. Kenanga.

1. Untuk pemerintah disarankan agar lebih memperhatikan kebutuhan dari pelaku usaha mikro, terutama peningkatan kegiatan atau pelatihan-pelatihan secara teknis terkait dengan produk jamur tiram putih.

\section{DAFTAR PUSTAKA}

Dafid, F. (2002). Manajemen Strategis. PT. Prenhallindo.

Dina Novia Priminingtyas, h. S. (2010). Prospek pengembangan Bisnis Sayuran Organik Model Pertanian Kota. Jurnal Universitas Paramadina

Kotler, P. (2000). Manajemen Pemasaran.Erlangga. Jakarta

Suryana. (2006). Ekonomi Pembangunan : Problematika dan Pendekatan. Salemba Empat. Jakarta

Tjiptono, Fandy, (2002), Strategi Pemasaran, Penerbit ANDI Yogyakarta.

Zhura, M. (2018). Pertumbuhan dan Produktivitas Jamur Tiram Putih (Pleurotus Ostreotus) pada Media

Ampas Teh Sebaga Substitusi Serbuk Gergaji. Reposituri Institut USU 